\title{
UK nuclear power research squeezed by market forces
}

\section{London}

THE United Kingdom Atomic Energy Authority, whose main business is research and development in support of the nation's nuclear power programme, has emerged from its second year of commercial operation with the announcement that it is to shed between 70 and 100 jobs at one of its eight laboratories. The authority, which employs around 14,000 people and has an annual turnover of some $£ 400$ million, became a trading fund in early 1986, having previously been government-funded through a grant-inaid. The authority's income is now derived exclusively from contracts, although the Department of Energy and the Central Electricity Generating Board (CEGB) remain the principal customers.

The authority's first year as a trading fund was seen through successfully, with the financial targets set by the government having been achieved. To do this the authority deliberately broadened its commercial base by expanding its nonnuclear research capability, thereby increasing its turnover by 15 per cent to $£ 38.4$ million - 9.2 per cent of total turnover.

Market forces are, however, now taking their toll. In October last year, Stuart Nelson, director of the authority's Northern Research Laboratories, launched a review of the laboratories' commercial future as part of a wide-ranging reassessment of the authority as a whole. The principal recommendation of Nelson's review, which was formally adopted on 17 March, is to run down activities at the Springfields laboratory in Lancashire, which is largely involved with the 'back end' of the fuel cycle, developing routes for dismantling fast reactor and other fuel elements. It is also the authority's centre for work on power fluidics, developing devices without moving parts for handling large volumes of active fluids in future plants such as the Thermal Oxide Reprocessing Plant at Sellafield, and houses the Structural Integrity Centre, which carries out fatigue and fracture testing of reactor components and other materials.

Much of Springfields' work will now be concentrated at the Northern Laboratories' other two sites at Risley and Windscale. The changes are necessary, says the authority, to reduce costs and to "match an expected decline in income and to become more competitive in seeking new business". The run-down will be phased over three years. The authority says the decline in income will arise mainly because work will become redundant as Magnox reactors approach the end of their lives, advanced gas-cooled reactors cease to be built and prior specification work on pressurized-water reactors has been completed.

However, another aspect of the authority's future income remains less predictable. As the CEGB prepares to be split into two parts and sold to private investors, the future of its nuclear research programme is far from clear. Already this year the CEGB has withdrawn from two Atomic Energy Authority projects. In January, the board announced that it would no longer contribute to the building of an $£ 18$ million laboratory for post-irradiation examination. Soon afterwards, at the end of February, the board said that from April it would withdraw from a 15-year, $£ 50$ million programme to dismantle the 33 MW advanced gas-cooled reactor at Windscale. The board had agreed to contribute $£ 25$ million to the scheme and had already committed $£ 5$ million. The Atomic Energy Authority is now seeking new partners.

Simon Hadlington

\section{Superphénix reactor} set to rise again?

Paris

THE French prototype fast-breeder reactor, Superphénix, which was shut down last year when a storage cylinder containing liquid sodium coolant developed a leak (see Nature 328,$100 ; 1987$ ), may be able to start again in October this year.

The plan, put to industry minister Alain Madelin, by engineers from Electricité de France (EDF), involves replacing the liquid sodium with inert argon gas. As the hairline cracks causing the leak have been found only in the inner liner of the cylinder (see Nature 331,$471 ; 1988$ ) the outer shell would be sufficient to maintain a sealed environment for fuel rods in transit to and from the reactor core, the experts say.

The cost of switiching to an argon coolant is estimated at FF300 million ( $£ 30$ million), compared to over FF400 million if the cylinder were to be replaced. But a change may have to be made in the procedure for operating the reactor. Fuel rods would have to be replaced only every three or four years, rather than annually as before, an operation which could itself take up to a year.

A final decision will not be taken until early summer, after safety experts have studied thousands of X-ray photographs of the cylinder and have carried out further tests.

Peter Coles

\section{German centre for California}

\section{Berkeley}

The West German Ministry for Research and Technology has decided that California is the place for computer science. In a matching-funds arrangement with a consortium of German industries, it has provided for the establishment of the International Center for Computer Science (ICSI), an independent research institute located near the University of California (UC) campus at Berkeley.

Although German computer science is already well-supported at the German National Center for Computer Science and several other university-associated laboratories, the money spent on ICSI is a concession to the reality of US leadership in computer science, and recognition that a US institute is more likely to draw the best international talent than one located in West Germany. The Germans will be rewarded for their effort with an international training ground for their young scientists, and the opportunity for collaboration on all levels, which they expect ultimately to enhance the quality of their science at home. The institute will focus on parallel computation, and will be headed by Jerome Feldman, recently appointed to the UC Berkeley faculty from the University of Rochester.

Originally established in 1986 with less than $\$ 1$ million in German seed money, ICSI operated with just a handful of staff until this month, when it moved to 14,000 feet of renovated office space. The Germans have pledged support approaching $\$ 5$ million a year for the next 5 years, renewable upon review. That will support some 30 scientists, as well as graduate students and postdoctoral researchers, says Feldman. The institute hopes to encourage other governments to be members and to bring in additional funding through US government research grants.

The sponsors do not have control over ICSI's direction, but German scientists hold two positions on the 9-member board of trustees. In addition, West Germany and any other supporting countries are likely to be more heavily represented among post-doctoral fellows, said Feldman. The institute has set up a competitive fellowship programme in West Germany, and expects to take up to 8 German postdoctoral fellows in the first year.

Research at ICSI will be 'pre-competitive' basic research, said Feldman, adhering to the institute's charter. His goal is to bring together computer scientists from diverse disciplines, as well as connectionists with backgrounds in biology, linguistics and psychology, to address the problems of parallel computing.

Marcia Barinaga 